\title{
THE BUDDHIST CONCEPT OF NIRVĀNA AND THE VISION OF DEIFICATION OR PERFECTION IN CHRISTIANITY
}

\author{
Fr. PhD Alexandru-Corneliu ARION \\ Lecturer, Faculty of Theology and Sciences of Education, \\ "Valahia" University of Târgovişte, ROMANIA \\ Email: alexcoarion@yahoo.co.uk \\ Motto: «Nirvāna is not the blowing out of the candle. It is the \\ extinguishing of the flame because day is come.» \\ (Rabindranath Tagore)
}

\begin{abstract}
.
The present paper tackles two concepts, peculiar to Buddhism and Christianity, which seem to be so close, but are, in reality, so different: nirvanna and deification. Buddha considers suffering as a characteristic reality of life as a whole and proposes the state of boddhi, as a way to escape from it, realizing or entering the state of nirvāna. Even though there are many interpretations of that, broadly, nirvana represents merely the Absolute; it is the "Nothing" of everything that has appeared; it is what transcends everything that man can experience, it is then, the Transcendent itself. Undoubtedly, nirvāna is the goal for which Buddhists strive. Attaining nirvāna is not like 'going to heaven' as Christians often understand it. In its turn, deification consists in acquiring not the divine nature, which is impossible, but the divine way of being, as persons in communion. Because God's way of being has been introduced into humanity by Jesus Christ, deification is found by sacramental union with Him. The idea of salvation as union is nowhere more thoroughly or more dazzlingly fulfilled than in the doctrine of the theosis ('deification') of the human person. Deification can be understood as 'Christification', or becoming ever-more Christ-like. The nirvānic eternity is always at odds with the eternity of the Christian communion, because it is empty of content, and therefore monotonous. The being anonymity realized in the state of mokșa or nirvāna is incompatible with the perfection of the human person, in the context of deification.
\end{abstract}

Keywords: Buddhism; nirvāna; deification; heaven; Jesus Christ; Buddha, samsāra; suffering; boddhi; perfection;

\section{INTRODUCTION}

The problems that always tormented human mind have been that of evil and suffering, seen as a pair or independent of one another. And perhaps in the larger field of the manifestation of the sacred, no other great religion has given such overwhelming importance to this problem, as did Buddhism. The Buddha affirms the universal existence of suffering and, at the same time, considers suffering as a characteristic reality of life as a whole. All that exists is suffering, which is why the whole Buddhist doctrine is concentrated on the suppressing the suffering, in any case it would be encountered. This is the first Noble Truth described by the Buddha, wherein results the other three, that specify the causes and at the same time the methods by which suffering can be eradicated. 
First, by the ideal it proposes, that is to suppress the suffering of all creatures, Buddhism is a religion that fascinates. The "project" itself is as tempting as possible, especially for the contemporary man, engaged on all coordinates in search of an altogether imminent and immanent happiness, hic et nunc. Happiness, this word so often invoked in the modern world (almost to the point of trivialization), has a pretty clear meaning in Buddhism. The entire "scaffolding" of Buddhist thought is built on an axiomatic intuition that is claimed to be a "corollary" of human aspirations ever: this idea is essentially a finding that "every man instinctively wants to achieve happiness, fullness, perfection and avoid suffering in his life. This feeling is not the fruit of education, culture or habit; it is rather intrinsic to the human being ". 1

Today, when West and East are no longer so far apart and no longer form two so distinct worlds, it is natural to have as close a mutual knowledge as possible. In addition, it is a reality of nowadays that we live in a world that is characterized mainly by pluralism and syncretism, from the religious point of view. ${ }^{2}$ The duty of a Christian remains today, as always, to know first and foremost his own faith, his own religious values, to cultivate them, and especially to share them with others. But in the context of contemporary religious pluralism, he has to delve more deeply into the multicolored landscape created by the religions and religious beliefs of the world. That is why we consider that the comparative study of religions must firstly highlight what is distinctive, and secondly, look for possible clues for a fertile interreligious dialogue, devoid of proselytizing intentions. ${ }^{3}$

In the depths of his being, each man possesses the desire for the Absolute. He cannot be otherwise. For on the basis of his own nature and due to his quality as 'image of God', he is bound to tend to the Absolute and to seek union with Him. In this regard, the Buddhist is like the Christian.

If all that is known - especially - about Buddhism is related to the conceptions of the state of enlightenment (boddhi) and of Nirvāna, it is then natural to try to understand where the fascination towards the message of this religion for the Western man comes from, who has, in his turn, a set of Christian values, out of which the state of deification (theosis) and that of heaven are not missing. Therefore, the present paper will debate these two fundamental beliefs of these emblematic religions: Nirvāna, the highest state that someone can attain versus heaven and the ontological state of the one who enters it.

\section{BUDDHIST METAPHYSICAL TENETS AND THE SILENCE OF BUDDHA}

About twenty-five centuries ago in northern India, Siddhārtha Gautama achieved nirvāna. That event ultimately changed the spiritual character of much of Asia and, more recently, some of the West. That something indeed happened is an indisputable fact. Exactly what happened has been an object of speculation, analysis, and debate up to the present day.

It has been said that the Buddha himself did not think, perhaps, of denying an ultimate and unconditioned reality, reached beyond the course of the cosmic process and

\footnotetext{
1 Geshe TASHI TSERING, Foundation of Buddhist Thought, vol. I, The Four Noble Truths, Wisdom Publications, Somerville, 2005, p. 9.

${ }^{2}$ Pr. Prof. Dr. Nicolae ACHIMESCU, Religii în dialog (Religions in dialogue), Trinitas Publishing House, Iaşi, 2006, pp. 13 sq.

${ }^{3}$ Constantin Crețu, Problema suferinţei în budism. O evaluare creştină (The problem of suffering in Buddhism. A Christian evaluation), PhD thesis in Theology, (abstract), Universitatea din București, 2013, p. 5.
} 
spiritual phenomena ${ }^{4}$, but merely avoided talking about it. In addition, Nirvāṇa represents merely the Absolute; it is the "Nothing" of everything that has appeared, that was constituted or that it is reconstituting; it is what transcends everything that man can experience, it is then, the Transcendent itself. ${ }^{5}$

The Buddha never consented to give his teaching the structure of a system. Not only did he refuse to discuss philosophical problems, he did not even issue pronouncements on several essential points of his doctrine - for example, on the state of the holy man in nirvāna. This silence early made possible differing opinions and finally gave rise to various schools and sects. The oral transmission of the Buddha's teaching and the composition of the canon raise numerous problems, and it would be useless to suppose that they will one day be satisfactorily solved.

Buddha's famous refusal to let himself be drawn into speculations of any kind is categorical. It is admirably illustrated in the famous dialogue with Māluṇkyaputta. This monk complained that the Blessed One gave no answers to such questions as: Is the universe eternal or noneternal? Finite or infinite? Is the soul the same thing as the body, or is it different? And so forth.

"There are," said Mālukyāputta, "questions that Buddha has left unsettled, has set aside and rejected. ... whether the soul and the body are identical; whether the soul is one thing and the body another; whether a saint exists after death; whether a saint does not exist after death; whether a saint both exists and does not exist after death; whether a saint neither exists nor does not exist after death. ... The fact that Buddha does not settle these questions does not please me. I will inquire. If he does not answer, in that case I abandon the religious life under the rule of Buddha."6

The Buddha then tells him the story of the man struck by a poisoned arrow. His friends and relatives fetch a surgeon, but the man exclaims:

"I will not let this arrow be drawn out until I know who struck me; also, whether he is a kșatriya or a Brahman ..., to what family he belongs; whether he is tall, short, or of medium height; from what village or city he comes. I will not let this arrow be drawn out before I know what kind of bow was drawn against me, ... what string was used on the bow, ... what feather was used on the arrow ..., how the point of the arrow was made.",

The man died without knowing these things, the Blessed One continued, just like one who would refuse to follow the way of holiness before solving one or another philosophical problem. Why did the Buddha refuse to discuss these things?

"Because it is not useful, because it is not connected with the holy and spiritual life and does not contribute to disgust with the world, to detachment, to cessation of desire, to tranquility, to profound penetration, to illumination, to Nirvāṇa!"8

\footnotetext{
${ }^{4}$ Cf. G. SiEgmund, Buddhismus und Christentum. Vorbereitung eines Dialogs, 2.Aufl., Steyler Verlag Sankt Augustin, 1983, pp. 215 sq.

${ }^{5}$ Nicolae ACHIMESCU, Budism și creștinism. Considerații privind desăvârşirea omului (Buddhism and Christianity. Considerations regarding human perfection), Junimea, Tehnopress Publisher, Iași, 1999, p. 230.

${ }^{6}$ Buddhist Scriptures, in Louis de la Vallée Poussin, The Way to Nirvāna. Six lectures on ancient Buddhism as a discipline of salvation, Cambridge: at the University Press, 1917, pp. 128-129. V. https://www.sacredtexts.com/bud/w2n/w2n07.htm\#fn_71

${ }^{7}$ Majjhima Nikāya, 1, in: Dialogues of the Buddha (The Dîgha-Nikâya), Translated from the Pâli by T.W. Rhys Davids, London, H. Frowde, Oxford University Press, 1899. V. https://www.sacredtexts.com/bud/dob/index.htm

${ }^{8}$ Majjhima Nikāya 1. 426.
} 
And the Buddha reminded Māluṇkyaputta that he had taught only one thing, namely: the four Noble Truths ${ }^{9}$.

In Buddhism, the Four Noble Truths (Sanskrit: catvāri āryasatyāni) are "the truths of the Noble Ones", the truths or realities for the "spiritually worthy ones". The truths are:

* dukkha (suffering, incapable of satisfying, painful) is an innate characteristic of existence with each rebirth;

* samudaya (origin, cause) of this dukkha is the "craving, desire or attachment";

* nirodha (cessation, ending) of this dukkha can be attained by eliminating all "craving, desire, and attachment";

* magga (path, Noble Eightfold Path) is the means to end this dukkha. ${ }^{10}$

The third Noble Truth proclaims that deliverance from pain (dukkha) consists in abolishing the appetites (taṇhā). It is equivalent to nirvāna. Interestingly, one of the names of nirvāna is "extinction of thirst" (taṇhākkaya).

The last two Truths are to be meditated on together. First, one affirms that the halting of pain is obtained by total cessation of thirst (tanhā), that is, "the act of turning away from it (from this thirst), renouncing it, rejecting it, freeing oneself from it, not attaching oneself to it" (Majjhima N. 1. 141). One then affirms that the ways that lead to the stopping of pain are those set forth in the Eightfold Path. The last two Truths explicitly state: (1) that nirvāna exists but (2) that it can be obtained only by special techniques of concentration and meditation. By implication, this also means that all discussion concerning the nature of nirvāna and the existential modality of the one who has achieved it has no meaning for him who has not reached even the threshold of that inexpressible state. ${ }^{11}$

\section{BUDDHIST CONCEPT OF NIRVĀṆA/ NIBĀNNA}

The study of Nirvāna has occupied the attention of scholars since the Buddhist literature first became known in the West; but it is probably true that at the present moment the general and popular notion of the meaning of the word is still vague and inaccurate. The easiest way to approach our subject is through etymology. Nirvāṇa is derived from Sanscrit roots, which mean "outblown" or "extinguished" in relation to a flame. We must therefore inquire how it came about that this particular fire symbology was adopted by the Buddha to express a spiritual state. But, we may ask, What is Nirvāna? What is it that is extinguished? The answer to this question is given in the Buddha's famous "Fire Sermon," delivered at Gaya to a large company of disciples. In a word, the whole of sentient existence is explained as "a burning." If the then current Idealism had said that there was a permanent indestructible Spiritual Reality behind the show of things; or if, on the contrary, Materialism of that day had declared that all phenomena have material causes, the Buddhist formula replied in these terms: Everything burns; everything is a flamelike in-force, a form of energy, clamant,

\footnotetext{
9 Mircea Eliade, A History of Religious Ideas, Volume 2: From Gautama Buddha to the Triumph of Christianity, Translated from the French by Willard R. Trask, The University of Chicago Press, Chicago and London, 1984, p. 132.

${ }^{10}$ Carol Anderson (2004), Robert E Buswell Jr. (ed.), Encyclopedia of Buddhism, MacMillan Reference, Thomson Gale. pp. 295-297. "This, bhikkhus, is the noble truth that is the way leading to the ending of suffering. This is the eightfold path of the noble ones: right view, right intention, right speech, right action, right livelihood, right effort, right mindfulness, and right concentration.[..] The Buddha taught the fourth truth, mārga (Pali, magga), the path that has eight parts, as the means to end suffering."

${ }^{11}$ Mircea ELIADE, A History of Religious Ideas, Volume 2, p. 141.
} 
affirmatory, in a state of perpetual change and combustion; it is a fire kept alight by fuel being continually added to it. ${ }^{12}$

In some important texts, like Mahavagga ${ }^{13}$, it is not stated that life is a burning, and death is its extinction; rather life and death are a fire; out of fire comes misery and suffering. Nirvāna is the dying down of the flames, the assuagement of the misery. Already there is a close analysis of the consciousness into various forms the eye, the touch, the mind, etc. and a tentative analysis of the passions.

A passage from the Jâtakas ${ }^{14}$ takes us a step further.

\begin{abstract}
"'Wherein does Nirvāna consist?' To him whose mind was already averse to passion, the answer came: 'When the fire of lust is extinct, that is Nirvāna; when the fires of hatred and infatuation are extinct, that is Nirvānan; when pride, false belief and all other passions and torments are extinct, that is Nirvāna. She has taught me a good lesson. Certainly Nirvāṇa is what I am looking for." 15
\end{abstract}

It must be noted that the passage from the Jātakas refers specifically to at least five fires, and leads us to believe that there are many others; but as the doctrine became more definite and formal, we find that the fires were reduced to three in number, namely (1) that which refers to all degrees of craving or attachment lust, infatuation and greed; (2) that which refers to all degrees of antipathy - hatred, anger, vexation or repugnance; and (3) that which refers to all degrees of ignorance - delusion, dullness and stupidity. ${ }^{16}$

From the epistemological theory point of view, a cessation (nirvāna) of dukkha (suffering) is possible through awakening (bodhi) to the nature of reality, involving a direct apprehension and engagement with reality - including both our objects and ourselves as subjects- as impermanent, interdependent and lacking any intrinsic reality. The term nibbāna (Pāli)/nirvāṇa is chosen carefully, and is often misunderstood by Western consumers of Buddhist literature. It is essentially a negative term, and figures in an elaborate fire-based metaphor ${ }^{17}$.

The idea of "Awakening" is an essential aspect of Buddhism. Awakening is the goal of Buddhism and it marks the end of the karma-rebirth cycle. As one reads how various Buddhists define this term, one may associate it with beliefs from other religious traditions, and appropriately so, as one could argue that the Hindu idea of mokșa, the Taoist idea of realizing the Tao, or even the descriptions of Christian, Muslim, or Jewish mystics seem similar. So, while arguably the Buddhist endpoint or solution to life's dilemmas may not be unique to Buddhism, it is an essential part of Buddhist belief.

\footnotetext{
${ }^{12}$ While the Buddha was preaching his "Fire Sermon" in India, Herakleitos at Ephesus was uttering his famous formula 'panta rei', "all flows"; nothing is permanent. He, too, reduced all things to primal fire. Cf. William Loftus HARE, Mysticism of East and West Studies in Mystical and Moral Philosophy, With an Introduction by J. Estlin Carpenter, D. Litt., Jonathan Cape Eleven Gower Street, London, 1923, pp. 175-176.

${ }^{13}$ The Mahavagga includes several sutta-like texts, including an account of the period immediately following the Buddha's Awakening, his first sermons to the group of five monks, and stories of how some of his great disciples joined the Samgha and themselves attained Awakening. See The Book of the Discipline, Part I, by I.B. Horner, London: Pali Text Society, 1982, pp. 36-37.

${ }^{14}$ The Jātaka tales are a voluminous body of literature native to India concerning the previous births of Gautama Buddha in both human and animal form. The future Buddha may appear as a king, an outcast, a god, an elephant - but, in whatever form, he exhibits some virtue that the tale thereby inculcates. V. "Jataka", in: Encyclopædia Britannica, Retrieved 2011-12-04.

${ }^{15}$ Introduction to the Jātakas, i. 58, in: Buddhism in Translations, transl. by Henry Clarke Warren, Motilal Banarsidass Publishers, Private Limited, Delhi, 2002.

${ }^{16}$ William Loftus HARE, Mysticism of East and West Studies in Mystical and Moral Philosophy, p. 178.

${ }^{17}$ R. GomBrich, R., What the Buddha Thought, London: Equinox, 2009.
} 
The Buddhist Awakening is often referred to by different terms, including nirvāṇa, enlightenment, and satori. As with the term karma, nirvāna has come to be widely used in American popular culture. There was, of course, a famous rock band of that name, but there is also to be found the term used in newspapers and popular magazines to connote something that is mystical or a peak experience (a "nirvāṇa like experience"). ${ }^{18}$ Nirvāṇa is defined in a dictionary as follows:

1) Hinduism a blowing out, or extinction, of the flame of life through reunion with the Brahma 2) Buddhism the state of perfect blessedness achieved by the extinction of individual existence and by the absorption of the soul into the supreme spirit, or by the extinction of all desires and passions 3 ) any place or condition of great peace or bliss. ${ }^{19}$

The third definition is the one that likely applies to the popular usage of the term nirvāna. The definition ascribed to Buddhism (\#2) is actually a conflation of Hindu and Buddhist ideas. Two of the terms, namely the "soul" and the "supreme spirit," find no place in Buddhism, although they would be acceptable translations for the Hindu concepts of the Atman and the Brahman, respectively. So, the first thing we can learn from this definition is the importance of seeking expert advice and double-checking the accuracy of anything you read about Buddhism! However, the remainder of the definition ${ }^{20}$ does provide an adequate provisional idea of what nirvāna actually means for a Buddhist. ${ }^{21}$

All Buddhists strive to reach nirvāna, if not in this life, then in their next life. Buddhism differs from those religions that place the resolution of life's drama postmortem; it insists that nirvāna can be attained prior to death. However, nirvāṇa can only be attained by a human being. It cannot be attained from either a subhuman or a superhuman realm of existence. Buddhism strongly encourages believers to strive for nirvāṇa in this very lifetime. After all, due to the effects of karma-rebirth, one may not be born human in the next life or, even if born human, one may not come to encounter Buddhist thought at all. ${ }^{22}$

In the Fire Sutta, Siddhartha Gautama is represented as saying that our life is led as though we are on fire. We are burned by dukkha, consumed by forces out of our control, and we are being depleted all the time by those forces. Nibānna is also a term with a very specific core meaning - the extinction of a flame, as in blowing out a candle or a lamp. Nibānna, or nirvānana, then, is not a positive attainment or state of being. Nor is it a state of complete non-being, of annihilation. Instead it is the state of no longer being driven, consumed and tormented (however unconsciously) by dukkha. ${ }^{23}$

\footnotetext{
18 The Japanese Buddhist term «Zen» is used in almost the same fashion and with a similar meaning in popular publications.

${ }^{19}$ Webster's New World College Dictionary, Fourth Edition, USA, Macmillan, 1999, p. 976.

20 "the state of perfect blessedness achieved by the extinction of individual existence . . . or by the extinction of all desires and passions".

${ }^{21}$ S. ColLINS, Nirvāṇa and other Buddhist Felicities: Utopias of the Pali Imaginaire, New York, 1998.

${ }^{22}$ Though all Buddhists strive to reach nirvāna, they do so in different ways. Some forms of Buddhism teach that only monks can hope to attain nirvāṇa. Laypersons try to accumulate as much positive karma as possible in this life in anticipation of a next life where they may be better placed to pursue monastic practice. Other Buddhists believe that it is through devotion to a Buddha that one can be delivered at death into a "pure land" of Awakening. Still other forms of Buddhism teach that even laypersons who work diligently at it may experience Awakening prior to death. See, inter alia, Leslie D. ALLDRITT, Religions of the World. Buddhism, Chelsea House Publishers, Philadelphia, 2005, p. 16.

${ }^{23}$ Dukkha is caused by a perceptual process. It is not that we engage with the world, or contemplate ourselves, and infer or decide that we or the things around us are permanent, independent and have identifiable intrinsic natures. Rather, we take the world and ourselves to be like that in our immediate
} 
One difficulty with the early Buddhist sacred texts is that they were not always clear or unequivocal about what was extinguished and from what one was emancipated. One prominent tendency was to understand nirvāna as a release from samsāra, the painful world of birth and death powered by passion, hatred, and ignorance. According to the early texts, the Eightfold Path leading to nirvāna is the only way to break free of this cycle and to eliminate the insatiable craving at its root. The Path is not merely a set of moral exhortations, but rather, a program of spiritual reconditioning that liberates one from the pain of samsāra ${ }^{24}$.

The Pali texts distinguished "nirvāṇa with remainder" from "nirvāṇa without remainder", or even more simply, enlightenment (nibbāna) from complete enlightenment (parinibbāna; Skt., parinirvāna). The Abhidharma ${ }^{25}$ traditions interpreted the distinction in the following way. After many lifetimes of effort and an overall improvement in the circumstances of rebirth, the person undertaking the Path finally reaches the stage at which craving and its attendant negative effects are no longer generated. This is the state of "nirvāna with remainder" because the residue of negative karmic effects from previous actions continues. The enlightened person still experiences physical pain, for example, as a consequence of the mere fact of corporeality, itself a karmic "fruit." Once these residues are burned off, as it were, the person will die and achieve the perfect "nirvāṇa without remainder." 26

One thing is undoubtedly: nirvāna is the goal for which Buddhists strive. Paradoxically, it too can become an object of craving. In that case the craving for nirvāna is an obstacle to be overcome Theravada ${ }^{27}$ Buddhism distinguishes two forms of nirvāna. These are called nirvāṇa with and nirvāṇa without a "substrate" (roughly a base made up of mental and physical elements). «Nirvāṇa with a substrate» is the nirvāṇa of the person whose passions have been blown out but who remains in the body until the consequences of earlier, craving motivated action (karma) work themselves out. It is described as a calm, cool bliss, beyond happiness and sadness. When the final flickers of karma go out, one enters

perceptual engagement - we see the world as constituted by entities with that nature. V. Jay L. GARFIELD, Engaging Buddhism. Why It Matters to Philosophy, Oxford University Press, New York, 2015, pp. 12-13.

${ }^{24}$ Thomas P. KASULIS (1987), Revised Bibliography, "Nirvāṇa", in: Encyclopedia of Religion, Second Edition, Lindsay JONES, editor in chief, vol. 10: Necromancy-Pindar, Thomson Gale, Macmillan Reference USA, p. 6628.

${ }^{25}$ Abhidharma (or Abhidhamma, in Pali) are ancient (3rd century BCE and later) Buddhist texts which contain detailed scholastic reworkings of doctrinal material appearing in the Buddhist sutras, according to schematic classifications. The Abhidharma works do not contain systematic philosophical treatises, but summaries or abstract and systematic lists. Cf. "Abhidhamma Pitaka", in: Encyclopadia Britannica. Ultimate Reference Suite, Chicago, Encyclopædia Britannica, 2008.

${ }^{26}$ Thomas P. KASUlis, "Nirvāṇa", in: Buddhism and Asian History, edited by Joseph Mitsuo Kitagawa and Mark D. Cummings, New York, 1989, pp. 395-408. A good introduction to the modern view of nirvāna from the standpoint of the only living tradition of Abhidharma, the Theravāda, is: Walpola RAHULA, What the Buddha Taught, rev. ed., Bedford, U.K., 1967, chap. 4. This small work is highly regarded for its ability to explain the gist of centuries of Abhidharmic analysis in a straightforward, accurate, and yet nontechnical manner.

27 Along with Mahayana Buddhism one of the two main forms of Buddhism. Theravada Buddhism is practiced mostly in southeast Asia: Sri Lanka, Myanmar (Burma), Thailand, Laos, and Cambodia. Theravada is a Pali term meaning "way of the elders," and devotees consider the school to be much closer than Mahayana to the Buddhism taught and practiced by the original Buddha and his first followers, although historically the Theravada was just one school among many. Followers prefer that name to Hinayana, which means "lesser vehicle" and is used in a derogatory fashion by Mahayana ("greater vehicle") Buddhists in reference to the Theravada school. Cf. Jeff HAY, Greenhaven Encyclopedia of World Religions, Gale, Cengage Learning, Detroit • New York • San Francisco • London, 2007, pp. 316 sq. 
parinirvāṇa, that is, the ultimate nirvāṇa, «nirvāṇa without a substrate». Theravada Buddhism teaches that there is no permanent self, and this leads to a very pointed question: Does a person continue to exist after entering parinirvāna? ${ }^{28}$

Centuries later, when Buddhism faced the split into Mahāyāna and Hināyāna currents, the former minimized the opposition between nirvāna and samsāra, renouncing the suggestion that nirvāna was an escape from the world of suffering. Instead, they thought of enlightenment as a wise and compassionate way of living in that world, generally maintaining that all distinctions are ultimately empty, including the distinction between nirvāna and saṃsāra. That is to say that nirvāṇa is not a separate state of existence that one enters; it is simply perceiving the world as it is, apart from our grasping and attachment. ${ }^{29}$

The adherents of the two major Indian branches of Mahāyāna philosophy, i.e. Mādhyamika and Yogācāra, each developed their own way of rejecting the escapism to which, it was thought, the Abhidharma interpretation led. One Mahāyāna strategy was to undercut the epistemological and logical bases for the sharp distinction between the concepts of nirvāna and samsāra. Without nirvāna there is no saṃsāra, and vice versa. How then could one be absolute and the other relative? ${ }^{\dot{3} 0}$

In effect, Mādhyamika thought radicalized the Buddha's original silence on this critical issue by trying to demonstrate that any philosophical attempt to characterize reality is limited by the logical interdependence of words or concepts. Assuming an isomorphic relationship between words and nonlinguistic referents, Nāgārjuna reasoned that the interdependent character of words precludes their referring to any absolute, nondependent realities. To the very extent one can talk or reason about nirvāna and samsāra, therefore, they must depend on each other. Neither can be absolute in itself. ${ }^{31}$

The discussion may go much further, because there is no single Buddhist view of Nirvāna. Apart from those seen above are also the views of the Chinese Tiantai and Huayan schools, of Chan (Zen) school, of Pure Land traditions or of the Esoteric traditions. Still, one does find in the Buddhist notions of nirvāna what Ludwig Wittgenstein would have called a 'family resemblance', that is, a group of characteristics that no single family member entirely possesses but that all members share to such an extent that the members of one family are distinguishable from the members of another. ${ }^{32}$

In this case, the Buddhist conceptions of Nirvāna share a set of qualities that can be summarized as follows.

\footnotetext{
28 As we already pointed out the Buddha refused to answer this question. He said it did "not lead to edification.” It simply distracted the questioner from seeking nirvāṇa.

${ }^{29}$ In addition, Mahayana Buddhists generally reject the idea that nirvāna is a goal that individuals pursue for themselves. Rather, motivated by compassion, they stress nirvāna's communal aspect. In the words of a Bodhisattva vow: "I cannot be happy unless all sentient beings are happy." V. "Nirvāṇa", in: The Encyclopedia of World Religions, Revised Edition, Robert S. Ellwood, gen. edit., Gregory D. Alles. assoc. edit., Facts On File, Inc., New York, 2007, p. 325.

30 This question was most clearly raised by the Perfection of Wisdom (Prajñāpāramitā) literature and philosophically analyzed in the Mādhyamika school founded by Nāgārjuna (c. 150-250 CE). See: David J. KaluPAHANA, Nagarjuna: The Philosophy of the Middle Way, Albany, N.Y., 1985. A good discussion of Nāgārjuna's basic position with respect to nirvāṇa also appears in Frederick J. STRENG, Emptiness: A Study in Religious Meaning, New York, 1967, pp. 69-81.

${ }^{31}$ Thomas P. KASULIS (1987), Revised Bibliography, "Nirvāṇa", p. 6629.

32 See Guy R. WelBon, The Buddhist Nirvāna and Its Western Interpreters, Chicago, 1968; K. SUKLA, Nagarjuna Bauddha Pratisthanam, Nature of Bondage and Liberation in Buddhist Systems: Proceedings of Seminar Held in 1984, Gorakhpur, India, 1988.
} 
1. Nirvāna is the release from ignorance about the way the world is. Because one does not understand the nature of human existence and the laws affecting human life, one lives in either a state of outright suffering or in a state of disharmony. Nirvāna is ultimately acknowledging and living by the truths of the world. In that respect, its orientation is this worldly.

2. The knowledge achieved by Nirvāna is not merely intellectual or spiritual. Nirvāna is achieved through a process of psychological and physical conditioning aimed at reorienting and reversing ego-centered forms of thinking and behaving. Nirvāna is achieved through and with the body, not despite the body.

3. Nirvānna has an intrinsically moral aspect. By eliminating all egocentric ideas, emotions, and actions, the enlightened person approaches others with either complete equanimity (wherein self and others are treated exactly the same) or with a compassionate involvement in alleviating the suffering of others (wherein self is subordinated to the needs of those less fortunate). Morality can be considered the alpha and omega of nirvāṇa. ${ }^{33}$

4. Although in any given context, one viewpoint is emphasized over the other, generally speaking, nirvāna can be understood from either a psychological or ontological perspective. Psychologically viewed, nirvanana is a radical change in attitude such that one no longer experiences the negative influence of egocentric thinking. If this perspective is misunderstood and overemphasized, however, it leads to a psychologism that holds that truth is simply in the mind without any connection to an external reality. The remedy for this distortion is to assert the ontological aspect of nirvānana. ${ }^{34}$

Ontologically speaking, nirvāna is the affirmation of the inherent goodness of the world and even of human nature. In this sense, it is not merely a kind of experience (as depicted by the psychological view), but is also the content or even ground of an experience. If this ontological viewpoint is overemphasized, on the other hand, it can lead to the distorted idea that diligence and practice are arbitrary or even unnecessary. ${ }^{35}$ The remedy is, conversely, to neutralize that distortion with more emphasis on the psychological side of nirvāna. What, after all, is nirvāṇa? It is a cooling off, a quenching of the fire of tanhā: but above all it is liberation. It is the jivvanmukti and mokșa of Buddhist tradition. But with regard to liberation we must ask: From what and to what? On the latter point, the 'to what', the Theravada school can be said to be embarrassingly silent, till we grasp the point: to that I shall come a little later. But as to the 'from what' thereis an embarrassment of riches of description. Consider the whole notion of dukkha, the theory of impermanence, the grand panorama of rebirth, the psychology of Buddhism, and so on. Still all that can be from one angle reduced to a single thought: impermanence. So we have the polarity or dialectic impermanent existence and, on the other hand, liberation. We believe - along with Ninian

\footnotetext{
${ }^{33}$ That is, the Path begins with accepting various rules and precepts of behavior, whereas nirvāna culminates in the open, moral treatment of other people and things.

34 Both the psychological and ontological views contain truths about the nature of nirvāna, but if either position is developed in such a way as to exclude the other, the result is a distortion of the Buddhist Path. For this reason, the two views coexist throughout Buddhist history, one view always complementing the other and checking any distortions that might arise out of a one-sided perspective. V. Thomas P. KASULIS (1987), Revised Bibliography, "Nirvāṇa", p. 6633.

${ }^{35}$ See David J. KaluPAHANA, Buddhist Philosophy: A Historical Analysis, foreword by G. P. Malalasekera, Honolulu: University Press of Hawaii, 1976, chap. 7. D. Kalupahana argues that early Buddhism consistently maintained that the achievement of nirvāna does not require, or entail, any transempirical form of perception. In this regard, Kalupahana is expanding on the theory that early Buddhism was primarily empirical in outlook, an interpretation first fully developed by K. N. JAYATILLEKE, Early Buddhist Theory of Knowledge, George Allen \& Unwin Ltd, London, 1963.
} 
Smart - that the analysis of impermanence is the essentially brilliant contribution of the message of the Buddha. ${ }^{36}$

\title{
3. NIRVĀṆA AND THE CHRISTIAN WAY TO PERFECTION (DEIFICATION)
}

The place of Buddhism among the religions has often been debated and definitions of religion have been enlarged to include those systems which appear to have no deity yet clearly have a long and powerful religious culture. Early Buddhism at least seemed not only to be agnostic about God, like the Jains, but also about the soul, and some have therefore maintained that Buddhism began as a philosophy or ethic and degenerated into a religion. Others, however maintain that Buddhism was religious from the outset and much richer than critical study might assume. ${ }^{37}$

But, attaining nirvāṇa is not like 'going to heaven' as Christians often understand it. We could not define nirvāna because our words and concepts are tied to the world of sense and flux. Experience was the only reliable proof. His disciples would know that nirvāna existed simply because their practice of the good life would enable them to glimpse it.

\begin{abstract}
"There is, monks, an unborn, an unbecome, an unmade, uncompounded. If, monks, there were not there this unborn, unbecome, unmade, uncompounded, there would not here be an escape from the born, the become, the made, the compounded. But because there is an unborn, an unbecome, an unmade, an uncompounded, therefore, there is an escape from the born, the become, the made, the compounded." 38
\end{abstract}

All that the Buddha could do was providing them with a raft to take them across to 'the farther shore'. When asked if a Buddha who had attained nirvāṇa lived after death, he dismissed the question as 'improper'. It was like asking what direction a flame went when it 'went out'. It was equally wrong to say that a Buddha existed in nirvāna as that he did not exist: the word 'exist' bore no relation to any state that we can understand. We shall find that over the centuries, Jews, Christians and Muslims have made the same reply to the question of the 'existence' of God. ${ }^{39}$

But when we talk about heaven or paradise, as a locus defining the attainment of Christian goal - in comparison with Buddhist nirvāṇa - we have to say that one cannot discuss about paradise alone, but along with the doctrine of man's perfection.

Firstly, heaven can denote the space above the earth; the dwelling place of angelic beings, the gods, or the highest God; and the dwelling place of those who will reside in eternity with the divine. This remains true for the biblical understanding of heaven, albeit with some modifications. The Israelites did not assign God a definite locale. Heaven was

\footnotetext{
${ }^{36}$ Ninian SMART, Concept and Empathy. Essays in the Study of Religion, edited by Donald Wiebe, Library of Philosophy and Religion, General Editor: John Hick, Macmillan Press LTD, chp. 11: Nirvāṇa and Timelessness, 1986, p. 119.

${ }^{37}$ First, because some of the notions held about Buddhism are not characteristic of it, and secondly, because other doctrines are rejected or ignored by the faithful. So that 'Studies of living Buddhism have shown that Buddhists differ very little from people in general." V. M. SPIRO, Buddhism and Society, 1971, pp. 10 sq.; People believe in Buddhas and gods, worship them and pray to them, speak of their souls and hope for personal rebirth, meditate little and regard Nirvāṇa as a far distant goal. Cf. Geoffrey PARRINDER, Mysticism in the World's Religions, Oneworld Publications, Oxford, 1995, pp 54-55.

${ }^{38}$ Udana 8.13, quoted and trans, in Paul STEINTHA, Udanan, London 1885, p.81. P. 26

39 The Buddha was trying to show that language was not equipped to deal with a reality that lay beyond concepts and reason. The only thing that counted was the good life; if it were attempted, Buddhists would find that the Dharma was true, even if they could not express this truth in logical terms. Cf. Karen ARMSTRONG, The History of God; from Abraham to the Present : The 4000-year Quest for God, Published by Vintage Books, London, 1999, p. 58.
} 
simply a part of Creation, distinguished from the earth by being stretched out above it. Some passages identify heaven as the domain from which God descends and to which he subsequently returns (Deut. 26:15), and others describe God as transcending both heaven and earth. ${ }^{40}$

The identification of heaven with God becomes conspicuous in the NT with the 'kingdom of heaven': Jesus teaches his disciples to pray to 'our Father in heaven' (Matt. 6:9); the Resurrected One is lifted up towards heaven (Acts 1:10); Christ 'is at the right hand of God' (Rom. 8:34); Paul assures that we have 'a house not made with hands, eternal in the heavens' (2 Cor. 5:1).

Early Christians commonly held that Jesus reopened the earthly paradise that had been shut since the fall. Christ's promise to the criminal on the cross seems to imply such a restoration (cf. Luke 23:43). St. John Chrysostom and St. John of Damascus supported this conception. Yet Theophylact (1050-1108), archbishop of Ochrid and Bulgaria, was wary of such conflation:

'Let no one say to me that paradise and the kingdom are one and the same. For eye hath not seen, nor ear heard, neither have ascended into the heart of man, the good things of the kingdom' (Luc. 23.43). ${ }^{41}$

Rather than a return to the beginning, a cyclical view of time, the kingdom of heaven is fulfillment and completion. What existence in this new creation will be like, even Paul can only express by negating present experience (1 Cor. 15:42 4). There will be unrestrained, continuous existence in the presence of God. There will be unrestrained, continuous existence in the presence of God. To discard this image as a utopian dream is to forget that Jesus Christ attained this fulfillment through his death and resurrection. Our immanent and perpetual yearning for self-transcendence, deification, perfection, and the elimination of death will be complete in life everlasting. ${ }^{42}$

In Christianity man's finitude is realized over against divine justice and divine love.

"No human being will be justified in his [God's] sight by works of the law. They are justified by his grace as a gift, through the redemption which is in Christ Jesus, whom God put forward as an expiation by his blood, to be received by faith" (Rom. 3:20, 24-25).

Man's finitude is realized in the light of God's righteousness as death, which is "the wages of sin" (Rom. 6:23). Accordingly, faith implies the death of the "old man" as well as the birth of the "new man" in Christ. Insofar as the death of the human ego is essential to salvation, no distinction can be made between Christian conversion and Buddhist awakening. In Christianity, however, because death is "the wages of $\sin$ " it is grasped within the context of man's personalistic and responsible relationship to God; due to his own injustice and sin, man can never be saved by his own efforts but only through faith in Christ as the redeemer, i.e., the incarnation of God. The divine-human relationship in Christianity is thus essentially vertical, with Christ, the mediator, originating in God as the transcendent or supernatural

\footnotetext{
40 'Will God indeed dwell on the earth? Even heaven and the highest heaven cannot contain you, much less this house that I have built!' (1 Kgs 8:27).

41 Hans SCHWARZ, "Heaven", in The Cambridge dictionary of Christian Theology, Edited by Ian A. McFarland, David A. S. Fergusson, Karen Kilby, Iain R. TorRance, Cambridge University Press, 2011, p. 206.

42 The Catechism of the Catholic Church declares: 'Heaven is the ultimate end and fulfillment of the deepest human longings, the state of supreme, definitive happiness’ (§1,024). Apud H. SCHWARZ, Eschatology, Wm. B. Eerdmans Publishing Company/Cambridge, UK, 2000.
} 
reality. Thus, in the last analysis it is an irreversibly vertical relationship with God as the superior. $^{43}$

It is clear that Buddhism, especially its original form, did not admit the supernatural in the form of God as creator, judge, or ruler, of the universe. This is so precisely because Buddhism is convinced that man's finitude is so deep that it cannot be overcome even by the supernatural. Now, this conviction is a pivotal point for Buddhism. And in this connection Buddhists would put this question to Christianity: Is man's finitude a kind of finitude which can be overcome by faith in God? What is the ground for such a faith? Dependent origination, a basic idea in Buddhism, indicates that there is no irreversible relationship even between man and "God," nature and the supernatural, the secular and the holy. ${ }^{44}$

Christianity transcends man and nature in "God," who, being the God of love and justice, is understood to be supernatural. The Christian loves his neighbor as himself in harmony with the first commandment to love God, who is his savior from sin, with his whole heart. Buddhism, on the other hand, transcends man and nature in the direction of "naturalness" or jinen, which is identical with Buddha nature or suchness. Thus, the "direction" or "location" of transcendence is not the same in Christianity and Buddhism, although the death of the human ego and the realization of the new man are in each case essential to transcendence ${ }^{45}$.

Deification. In understanding the difference concerning human nature and the eschatology between Buddhism and Christianity, one has to turn to the Eastern Christian teaching on man's perfection or deification. And to understand the departing point of this poignantly bold concept one has to refer to another main concept, namely that of contemplation.

We should distinguish two different kinds of elements constituting the concept of contemplatio: on the one hand, Platonic and Aristotelian definitions, on the other, a biblical element from the Old Testament (essentially in the figures of Moses and Elijah), as well as from the New Testament - Martha and Mary (Lk 10:38-42) and Paul's ecstasy (Acts 9:3-9, 22:6-11. The Platonic and Aristotelian definitions of contemplation - theoria - do not coincide. For Plato, theoria was the high point of knowledge delivering the best of the human being (Rep. VII 532 c.) It is exercised by the nous (Phaedrus 247c) and relates to love (Symposium $192 \mathrm{c}$ ) by being part of the Good, a good that is beyond being (The Republic 509 b). This definition opens for the Greek Fathers the possibility of deification through theoria. ${ }^{46}$

\footnotetext{
${ }^{43}$ Even the unio mystica, in which the soul of man joins to God in an indescribable experience, is not altogether an exception. And this irreversible relationship between man and God is inseparably bound to man's deep realization of his own finitude. Cf. The Buddha Eye: An Anthology of the Kyoto School and Its Contemporaries, revised edition, Spiritual Classics Series, Frederick FRANCK, ed., World Wisdom, Inc., 2004, p. 154.

${ }^{44}$ This is especially clear in Mahāyāna Buddhism, which stresses the relationship of soku as seen in its familiar formula "saṃsāra-soku-nirvāṇa" (saṃsāra as it is, is nirvāṇa). Accordingly, "naturalness" or jinen is not something merely immanent, nor a counterconcept of the supernatural, but implies the total negation of the supernatural or transcendent. Cf. A. MASAO, "Dōgen on Buddha-nature," The Eastern Buddhist, IV/1, 1971, pp. 28-71.

${ }^{45}$ Frederick FRANCK, ed., The Buddha Eye: An Anthology of the Kyoto School and Its Contemporaries, p. 155 .

${ }^{46}$ For details: Frédéric NeF, "Contemplation", in Jean-Yves LACOSTE, editor, Encyclopedia of Christian Theology, vol. 2: G-M, Routledge, Madison Avenue, New York • London, 2005, pp. 353-360; Guigues du PONT, Traité sur la contemplation, Analecta Cartusiana 72, 2 vols., Salzburg, 1985; R. ARNOU, Le thème néoplatonicien de la contemplation créatrice chez Origène et chez saint Augustin, Rome, 1932; H. U. von
} 
In Aristotle, on the other hand, theoria is defined as the high point of virtuous life, "life by the intellect" (Nicomachean Ethics X, 7), which opens the way for "divinization of the intellect". For Plato, theoria is something mysterious (Symposium 209 e), a revelation of the Beautiful that is inaccessible to any conception (Symposium 211 a), an ecstatic science of the Beautiful itself (Symposium $211 \mathrm{c}$ ) - in a word, an intuitive knowledge of the absolute. ${ }^{47}$

If the West is concerned with sin and the fall from grace, the anthropological "simplicity" of the East focuses upon its stark consequence, death. St. Athanasius the Great, for example, teaches that "man is mortal by nature, since he has issued from nothingness" (PG 25, 104 C). Sin cuts us off from God and renews the menace of death. The soul is not intrinsically immortal, but equally threatened by the return to nothingness, for it too is created. The Western tendency to distinguish mortal body and immortal soul is thus overcome: it is body and soul, "both together," that have been created in the image of God. ${ }^{48}$

The image tends toward likeness, which is deification: "the image predestines man to theosis" ${ }^{49}$. Gregory of Nazianzus echoes St. Basil's words, that man is a creature who has "received the order to become a god" (PG 36, 560 A), although the distinction of essence and energies is found more clearly in Basil (PG 32, 869 A-B) than in Gregory (PG 36, 317 B-C). The Eucharist particularly accomplishes this deification (PG 35, 1200 B). Gregory of Nyssa corrects the impression that the journey into God has an end in a static "vision" when he teaches that, even in the world to come, we shall ascend "from beginning to beginning, through a series of beginnings that never ends" (PG 44, 941 C). He adds that "Christianity is

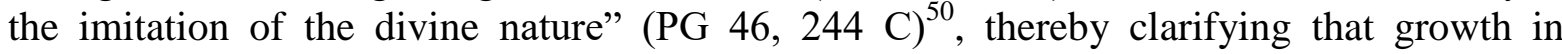
likeness to God (for which free cooperation, synergy, with his grace is needed) is growth toward being a person who embodies the fullness of human nature, just as, in God, each person bears the totality of the divine nature.

Thus, deification consists in acquiring, not the divine nature, which is impossible, but the divine way of being, as persons in communion. Because God's way of being has been introduced into humanity by Jesus Christ, deification is found by sacramental union with Him, reinforced by the Jesus Prayer in hesychasm. John Zizioulas (1975) thinks that, because of the priority it traditionally gives to nature over person in its Trinitarian theology, the West has never really accepted theosis, because man can never acquire God's nature ${ }^{51}$. However, restoring priority to the person enables the concept to be embraced fully.

The idea of salvation as union is nowhere more thoroughly or more dazzlingly fulfilled than in the doctrine of the theosis ('deification') of the human person. The Fathers taught that the divine likeness is something towards which we strive; it is the realisation of

\footnotetext{
BALTHASAR, Schwestern im Geist: Therese von Lisieux und Elizabeth von Dijon, Einsiedeln, 1970; F. NEF, "Caritas dat caritatem: la métaphysique de la charité dans les sermons sur le Cantique des Cantiques et l'ontologie de la contemplation," in R. BRAGUE (Ed.), Saint Bernard et la philosophie, Paris, 1993, pp. 87109.

${ }^{47}$ Ibid, p. 353. The Aristotelian and Platonic ideas of theoria underwent an attempt at unification on the one hand within pagan and possibly anti-Christian Neoplatonism (Plotinus and Proclus) and on the other within the Christian Platonism of the Greek Fathers (Origen, Gregory of Nyssa, and Maximus the Confessor), including and above all in its most radical attempts at negative theology (Pseudo-Dionysius).

48 St. Athanasius, PG 150, 1361 C, apud Paul McPartlan, "Holiness", in: Jean-Yves Lacoste, ed., Encyclopedia of Christian Theology, p. 715.

${ }^{49}$ Paul Evdokimov, L'Orthodoxie, Desclée deBrouwer, Paris, 1979.

${ }^{50}$ Paul MCPARTLAN, "Holiness", in: Jean-Yves LACOSTE, Encyclopedia of Christian Theology, p. 715.

${ }^{51}$ J. D. ZIZIOULAS, "Human Capacity and Human Incapacity: A Theological Exploration of Personhood," in: Scottish Journal of Theology, (SJTh) 28, Edinburgh, 1975, pp. 401-48.
} 
the gift and vocation implanted in us with the divine image. St Athanasius's oft-repeated dictum, 'He [the Word of God] became human so that we could become divine', is but one iteration of a teaching that resonates throughout the Fathers. ${ }^{52}$ Although neither deification, nor life itself, is ours by right - it is a gift of God's grace - the Fathers saw it as the natural fulfillment of the human being: 'The life that bears a likeness to the divine is completely in accord with human nature. ${ }^{53}$ But however stunning and unimaginably mysterious this doctrine may (and should) sound, it also has a concrete moral dimension. St Gregory Palamas equated the divine energies with the divine will: participating in the energies is participating in God's will, doing his commandments. We naturally become more and more 'God-like' the more we harmonise our own will with His. As with everything else holy, good and saving, our supreme example for deification is Christ himself, who unites the human and the divine in his person, on every level, including that of the will. Deification can be understood therefore as 'Christification', or becoming ever-more Christ-like. ${ }^{54}$

Human vocation is to become by grace everything that Christ is by nature. In other words, our work is to participate in God's work and in His will, and in His light and His glory, to the point where, while remaining created human persons, we become also partakers of the characteristics of divinity itself ${ }^{55}$. In that ascent - and through all the 'crosses' that it entails - we join the One who descended for our sake, who, while remaining uncreated and divine, became also a partaker of the characteristics of humanity.

Deification goes beyond natural perfection, for if it simply perfected the rational creature qua rational creature, the deified would not be 'born of God', as stressed out Gregory Palamas, in his famous Triads. ${ }^{56}$ All men, together with the angels, would have been gods by virtue of their rationality. Deification is more than the achievement of moral excellence. It is a supernatural gift that transforms both mind and body, making divinity visible (Triad 3.1.33). For what Christ is by nature the Christian can become by grace:

\begin{abstract}
So, when the saints contemplate this divine light within themselves, seeing it by the divinising communion of the Spirit, through the mysterious visitation of perfecting illuminations - then they behold the garment of their deification, their mind being glorified and filled by the grace of the Word, beautiful beyond measure in his splendor; just as the divinity of the Word on the mountain glorified with divine light the body conjoined to it. For 'the glory which the Father gave him', He himself has given to those obedient to him, as the Gospel says, and 'he willed that they should be with him and contemplate his glory' (John 17: 22, 24) (Triad 1.3. 5). ${ }^{57}$
\end{abstract}

\footnotetext{
${ }^{52}$ Peter BoutenefF, "Christ and salvation", in The Cambridge Companion to Orthodox Christian Theology, Edited by Mary B. Cunningham and Elizabeth ThEOKRITOFF, Cambridge University Press, 2009, p. 104.

${ }^{53}$ St Gregory of Nyssa, Homily I on Ecclesiastes, in: PSB, vol. 29: Gregory of Nyssa, Writings, Part I, transl. by Rev. prof. Dumitru Stăniloae and Rev. Ioan Buga, Institutul Biblic si de Misiune al Bisericii Ortodoxe Române, București, 1982.

${ }^{54}$ See Panayotis Nellas, Deification in Christ: Orthodox Perspectives on the Nature of the Human Person, Crestwood, NY: SVS Press, 1987, esp. pp. 115-159.

${ }^{55}$ According to II Peter (1:4): "by which have been given to us exceedingly great and precious promises, that through these you may be partakers of the divine nature, having escaped the corruption that is in the world through lust."

${ }^{56}$ St GrEgORY Palamas, Triad 3.1.30, in: The Triads, ET selected texts Nicholas Gendle, CWS. London, SPCK, 1983.

57 Apud Norman Russell, The Doctrine of Deification in the Greek Patristic Tradition, Oxford Early Christian Studies, General Editors: Gillian Clark \& Andrew Louth, Oxford University Press Inc., New York, 2004, p. 306. See also, the Romanian translation of this masterpiece by Dragoș Dâscă: Invăţătura despre îndumnezeire în tradiţia patristică greacă, „Patristica” Collection, Doxologia Publisher, Iași, 2015.
} 
Maximus the Confessor, Symeon the New Theologian, Gregory of Sinai, and Gregory Palamas are figure prominently in the famous Eastern collection of Philokalia. Their teaching on deification through participation in the divine light became familiar to a wide monastic readership. St Seraphim of Sarov, the best-known of the Russian nineteenthcentury mystics, was seen by more than one of his disciples transfigured by an intense light. 'Remember the transfiguration of the Lord on Mount Tabor', the staretz is reported to have said.

\begin{abstract}
'When Moses and Elijah came to him then, in order to hide the shining light of divine grace which blinded the disciples, a cloud, it is said, overshadowed them. In this manner the grace of the All-Holy Spirit of God manifests itself in an indescribable light to all those in whom God manifests its action'. ${ }^{58}$
\end{abstract}

In more recent times a remarkable testimony to the continuity of the same teaching and experience of transfiguration has been borne by St Silouan of Mount Athos and his disciple, Archimandrite Sophrony. ${ }^{59}$ If the repentant sinner perseveres and 'consciously abides in the Holy Spirit', says Sophrony, 'the vision of immortal glory and undying light is vouchsafed to him' and he becomes a participant in the life of Christ, having become "without beginning" (not in essence but by grace) ${ }^{60}$ Such perseverance is directed not towards the pursuit of mystical experience but to making Christ fully effective in the Christian's life. ${ }^{61}$

\title{
CONCLUSION
}

Christianity and Buddhism can both be termed 'religions of salvation,' even if the expression sounds more Christian than Buddhist. In both, there is a supreme goal to be attained, which in Christian terms is sometimes called 'the peace of God which passeth understanding.' Buddhists would omit the words 'of God,' but the rest is perhaps as good a phrase as we can find to describe, or rather designate, Nirvāna. Both religions would agree that the mysterious, indeed incomprehensible 'Unborn' (to use the Buddhist term) is the guarantee of deliverance. How this deliverance can come about is another matter concerning which, indeed, Christians differ among themselves. But in considering the differences between Buddhism and Christianity, we should never lose sight of the fundamental agreement at a very deep level - so deep indeed that it can all too easily be overlooked or denied. We can express this agreement schematically thus:

$\begin{array}{cc}\text { Buddhist Nirvāna } & \text { Unborn } \\ \text { (impersonal) } & \text { Christian God } \\ \text { (personal) }\end{array}$

\footnotetext{
${ }^{58}$ Sergius BolshaKOFF, Russian Mystics, CSS 26. Kalamazoo, Mich.: Cistercian Publications, 1977, p. 135.

${ }^{59}$ Archimandrite Sophrony Sakharov - canonized at the end of 2019 by the Ecumenical Patriarchy - came to England in 1959 and founded an Orthodox monastery at Tolleshunt Knights in Essex. His books on St Silouan have circulated widely. Less well known is his spiritual testimony (Sophrony 1988) in which he vividly describes his own experience of uncreated light. Interestingly, this is balanced by the equally powerful experience of the mind's descent into hell.

${ }^{60}$ Archimandrite SopHrOnY (Sakharov), We Shall See Him as He Is, Trans. Rosemary Edmonds, Tolleshunt Knights: Stavropegic Monastery of St John the Baptist, 1988, p. 45.

${ }^{61}$ A curious early twentieth-century aberration in the development of the hesychastic tradition may be mentioned here, the heresy of the name-worshippers, which arose from treating the name itself of God as a separate hypostasis. That the Orthodox Church pronounced it a heresy underlines its opposition to the multiplication of hypostases in the Godhead. Norman RuSSELL, The Doctrine of Deification in the Greek Patristic Tradition, p. 311.
} 
Thus, without arguing about who is right, we can say that the terms 'Nirvāna' and 'God' both refer to the Unborn which, being incomprehensible to the ordinary mind, is differently interpreted. It may be objected that the two terms 'Nirvāna' and 'God' are not strictly parallel, since Nirvāna corresponds not so much to God as such, but to the 'peace of God.' However, consideration of at least some types of Christian mysticism may suggest that this is possibly 'a distinction without a difference.' 62

The Unborn cannot be defined, or imagined, or reached by any ratiocinative (i.e. subtle, pedantic reasoning) process. It can, however, be realized. But long before this full realization is attained, it can be more or less dimly intuited. To such an intuition it is 'felt' to be an ultimate refuge in a world of flux. Christians call it 'God' and give it the attributes of a loving Father. For Buddhists this is illegitimate: the Ultimate is 'signless.' This has absurdly led some learned Buddhist book-scholars, finding nothing 'graspable' about it, to equate Nirvāna with total extinction indistinguishable from that postulated by the materialists, only postponed, improbably, to the death of the Arahant. They should know better. But Christians too know that they should not try to imagine God. ${ }^{63}$ The early Buddhist texts primarily approached Nirvāna as a practical solution to the existential problem of human anguish. Specifically, they maintained that by undertaking a disciplined praxis the Buddhist practitioner can achieve a nondiscursive awakening (bodhi) to the interdependent nonsubstantiality of reality, especially of the self. With that insight, it was believed, one could be released from the grips of insatiable craving and its resultant suffering. ${ }^{64}$

The Buddhist conception of Nirvāna presents the most radical contrast to Christian eschatology. The Christian hopes for infinite continuation of his entire personality, not only of his soul but also of his body resurrected from dust to a new life. The Buddhist, however, wishes to be extinguished completely, so that all mental and corporeal factors which form the individual will disappear without a remainder. Nirvāna is the direct opposite of all that constitutes earthly existence. It is a relative Naught in so far as it contains neither the consciousness nor any other factor that occurs in this world of change or could possibly contribute to its formation. Not wrongly, therefore, has Nirvāna been compared to empty space in which there are no differentiations left, and which does not cling to anything. In strongest contrast to the world which is impermanent, without an abiding self-nature and subject to suffering, Nirvāṇa is highest bliss, but a bliss that is not felt, i.e., beyond the happiness of sensation ${ }^{65}$.

In the conception of the final goal of deliverance there is expressed the ultimate and most decisive contrast between the Christian and the Buddhist abnegation of the world. The Christian renounces the world because it is imperfect through sin, and he hopes for a personal, active and eternal life beyond in a world which, through God's power, has been freed from sin and purified to perfection. But the Buddhist thinks that an individual existence

\footnotetext{
${ }^{62}$ M. O' C. Walshe, “Buddhism and Christianity: A Positive Approach” (With Some Notes on Judaism), Buddhist Publication Society, Kandy • Sri Lanka, 1986, p. 5.

${ }^{63}$ As a Romanian priest (Elder Cleopa from Sihastria o.n.), speaking of the Orthodox 'Jesus Prayer,' told to someone, 'The first law, when we begin to pray, is not to "fancy" anything or imagine anything, because God Himself does not come under the sway of the imagination. Fantasy is a stumbling block to our union with God'. Ronald Eyre on The Long Search, Collins 1979, p. 162.

${ }^{64}$ For details: Dr. Remus Rus, „Concepţia despre om în marile religii” (”The conception of man in the great religions"), in: Glasul Bisericii, Bucharest: Institutul Biblic şi de Misiune al B.O.R. Publisher, 1978, no. 7-8, pp. 832-835.

Helmuth Von GlasenapP, "Buddhism and Christianity and Buddhism and the Vital Problems of our Time”. Two Essays, Buddhist Publication Society, Kandy• Sri Lanka, 1963, p. 12.
} 
without becoming and cessation, and hence without suffering, is unthinkable. He believes though, that in future, during the ever-recurring cyclical changes of good and bad epochs, also a happy age will dawn upon mankind again. But that happy epoch will be no less transient than earlier ones have been. Never will the cosmic process find its crowning consummation in a blessed finality. Hence there is no collective salvation, but only an individual deliverance. While the cosmic process following unalterable laws continues its course, only a saint who has become mature for Nirvāna will extinguish like a flame without fuel, in the midst of an environment that, with fuel unexhausted, is still burning. ${ }^{66}$

In most cases Nirvāna is described in negative terms such as "cessation" (nirodha), "the absence of craving", "detachment", "the absence of delusion," and "the unconditioned". Although in the nikayas and subsequent Abhidharma School commentaries there are scattered positive references to, for instance, "happiness" (sukha), "peace", and "bliss", and to such metaphors of transcendence as "the farther shore", the negative images predominate. Indeed, the word Nirvāna itself means "extinction", and other words used synonymously with it, such as mokșa and mukti, refer to emancipation. One difficulty with the early texts, however, is that they were not always clear or unequivocal about what was extinguished and from what one was emancipated. One prominent tendency was to understand Nirvāna as a release from samsara, the painful world of birth and death powered by passion, hatred, and ignorance. $^{67}$

The union with God does not, in any case, transcend the natural limit of creation; it does not mean "dissolution" of man in God, respectively "Nothing", as the representatives of Kyoto $^{68}$ argue, but it is a work of the grace of God, anchored in the moral plane and corresponding with human nature. The union of God with man is not realized in the divine being, but in the uncreated divine energies, which flow out from the divine being and reveal themselves outside. It is obvious that both the Fathers of the Church and Buddhists state that, on this last step of the path to perfection, the deified and the nirvānized respectively, became "without beginning" and "without end". However, it must be borne in mind that the affirmation of the Church fathers does not refer to a loss, to a dissolution of man, to his "cosmicization", as in Buddhism, but to the fact that man commune from the divine grace and thereby "pours out" from His being, in the sense that he becomes immortal from mortal, clean from unclean, from a transient an eternal, and of a man, absolute God.",69

In the Christian sense, the sanctity of man is achieved only through the encounter with the absolute Person. In the face of an impersonal "Absolute", such as the Buddhist "Absolute Nothing", one cannot feel the urge for absolute purity, sincerity and transparency,

\footnotetext{
${ }^{66}$ Ibid, p. 12. The different attitude towards the world and its history tallies also with the dissimilar evaluation given to other religions by Christians and Buddhists respectively. Christianity, being convinced of the absolute superiority of its own faith, has always questioned the justification of other forms of faith. Buddhism, however, does not believe that man has to decide about it within a single life on earth. The Buddhist, therefore, regards all other religions as first steps to his own. Consequently, in the countries to which Buddhism spread, it did not fight against the original religions found there, but tried to suffuse them with its own spirit. Therefore, Buddhism has never claimed exclusive, absolute or totalitarian authority.

67 Alexandru-Corneliu ARION, "The metaphysical frameworks of Buddhism. Premises of the dialogue between Buddhism and Christianity", in International Journal of Orthodox Theology (IJOT), Daniel Munteanu (edit.), 6:2 (2015), p. 170.

68 The Kyoto School (Kyōto-gakuha) is a group of $20^{\text {th }}$ century Japanese thinkers who developed original philosophies by creatively drawing on the intellectual and spiritual traditions of East Asia, those of Mahāyāna Buddhism in particular, as well as on the methods and content of Western philosophy.

${ }^{69}$ St. Gregory of Nyssa, "Cuvântul 7 la Fericiri”, P.G. 44, col. 1280C; St. Basil the Great, On Holy Spirit, 15, P.G., 32, col. 132B.
} 
and that is because only an absolute Person can greet you with absolute purity and power. ${ }^{70}$ From the Christian perspective, to an impersonal "Absolute", such as that of Nāgārjuna's suunyatā, cannot be attributed purity in its own sense, because purity in its true sense is a matter of intention, of thoughts, of subjective interiority, within conscious acts. Only the Absolute as a Person can be wholly clean by itself, by His being, but not in the limited sense. ${ }^{71}$ The nirvānic eternity is always at odds with the eternity of the Christian communion, because it is empty of content, and therefore monotonous. It is, in fact, an emptied time of substance, since nothing is expected anymore, nothing is done out of it. As Father Staniloae argues, such a time - which we identify with the nirvānic one - is "a unique state without end ... the impossibility or black eternity, the darkest outside of existence, the absence of life" ${ }^{, 72}$. Mokșa or Nirvāna, Christian or Islamic paradises are not one and the same. The being anonymity realized in the state of mokșa or nirvanna is incompatible with the perfection of the human person, in the context of deification. ${ }^{73}$ And yet, the fruitful results of the encounter between the religions of today's world, on the social field, and beyond, are more than encouraging, for they show us that God has been working until now (cf. John 5: 17) and that ultimately we will all be one in Jesus Christ, our Lord.

\section{BIBLIOGRAPHY:}

[1] **Buddhism in Translations, transl. by Henry Clarke Warren, Motilal Banarsidass Publishers, Private Limited, Delhi, 2002.

[2] **Dialogues of the Buddha (The Dîgha-Nikâya), Translated from the Pāli by T.W. Rhys Davids, London, H. Frowde, Oxford University Press, 1899.

[3] ** Encyclopadia Britannica. Ultimate Reference Suite, Chicago, Encyclopædia Britannica, 2008.

[4] **The Book of the Discipline, Part I, by I.B. Horner, London: Pali Text Society, 1982.

[5] **Webster's New World College Dictionary, Fourth Edition, USA, Macmillan, 1999.

[6] ACHIMESCU, Nicolae, Religii în dialog (Religions in dialogue), Trinitas Publishing House, Iaşi, 2006.

[7] —. Budism și creștinism. Considerații privind desăvârșirea omului (Buddhism and Christianity. Considerations regarding human perfection), Junimea, Tehnopress Publisher, Iași, 1999.

[8] AlldritT, Leslie D., Religions of the World. Buddhism, Chelsea House Publishers, Philadelphia.

[9] Anderson, Carol; Buswell Jr., Robert E., ed., Encyclopedia of Buddhism, MacMillan Reference, Thomson Gale, 2004.

[10] ARION, Alexandru-Corneliu, "The metaphysical frameworks of Buddhism. Premises of the dialogue between Buddhism and Christianity", in International Journal of Orthodox Theology (IJOT), Daniel Munteanu (edit.), 6:2 (2015).

[11] Armstrong, Karen, The History of God; from Abraham to the Present : The 4000-year Quest for God, Published by Vintage Books, London, 1999.

[12] BolShaKofF, Sergius, Russian Mystics, CSS 26. Kalamazoo, Mich.: Cistercian Publications, 1977.

[13] BoutenEFF, Peter, "Christ and salvation", in The Cambridge Companion to Orthodox Christian Theology, Edited by Mary B. Cunningham and Elizabeth Theokritoff, Cambridge University Press, 2009.

[14] Collins, S., Nirvāṇa and other Buddhist Felicities: Utopias of the Pali Imaginaire, New York, 1998.

[15] Crețu, Constantin, Problema suferinţei în budism. O evaluare creştină (The problem of suffering in Buddhism. A Christian evaluation), PhD thesis in Theology, (abstract), Universitatea din București, 2013.

[16] Eliade, Mircea, A History of Religious Ideas, Volume 2: From Gautama Buddha to the Triumph of Christianity, Translated from the French by Willard R. Trask, The University of Chicago Press, Chicago and London, 1984.

[17] ELLWOOD, Robert S., gen. edit., The Encyclopedia of World Religions, Revised Edition, Gregory D. Alles. assoc. edit., Facts On File, Inc., New York, 2007.

\footnotetext{
${ }^{70}$ Dumitru StăNILOAE, Teologia Dogmatică Ortodoxă (Orthodox Dogmatic Theology), vol. I, Institutul Biblic şi de Misiune al B.O.R. Publishing House, Bucharest, 1978, p. 267.

${ }^{71}$ Nicolae ACHIMESCU, Buddhism and Christianity. Considerations regarding human perfection, p. 250.

${ }^{72}$ Dumitru StĂNILOAE, Teologia Dogmatică Ortodoxă (Orthodox Dogmatic Theology), vol. I, pp. 194-195.

${ }^{73}$ Remus RUS, "The conception of man in the great religions", pp. 902-903.
} 
[18] Evdokimov, Paul, L'Orthodoxie, Desclée deBrouwer, Paris, 1979.

[19] FrancK, Frederick, ed., The Buddha Eye: An Anthology of the Kyoto School and Its Contemporaries, revised edition, Spiritual Classics Series, World Wisdom, Inc., 2004.

[20] GaRfIELD, Jay L., Engaging Buddhism. Why It Matters to Philosophy, Oxford University Press, New York, 2015.

[21] GlasenaPP, Helmuth Von, "Buddhism and Christianity and Buddhism and the Vital Problems of our Time”. Two Essays, Buddhist Publication Society, Kandy • Sri Lanka, 1963.

[22] GoMBriCH, R., What the Buddha Thought, London: Equinox, 2009.

[23] Gregory, of Nyssa, Writings, Part I, in: PSB, vol. 29, transl. by Rev. Dumitru Stăniloae and Rev. Ioan Buga, Institutul Biblic si de Misiune al Bisericii Ortodoxe Române, București, 1982.

[24] GregORY Palamas, The Triads, ET selected texts Nicholas Gendle, CWS. London, SPCK, 1983.

[25] HARE, William Loftus, Mysticism of East and West Studies in Mystical and Moral Philosophy, With an Introduction by J. Estlin Carpenter, D. Litt., Jonathan Cape Eleven Gower Street, London, 1923.

[26] HaY, Jeff, Greenhaven Encyclopedia of World Religions, Gale, Cengage Learning, Detroit • New York • San Francisco • London, 2007.

[27] JAYATILLEKE, K. N., Early Buddhist Theory of Knowledge, George Allen \& Unwin Ltd, London, 1963.

[28] KaluPahana, David J., Nagarjuna: The Philosophy of the Middle Way, Albany, N.Y., 1985.

[29] — Buddhist Philosophy: A Historical Analysis, foreword by G. P. Malalasekera, Honolulu: University Press of Hawaii, 1976.

[30] KasUlis, Thomas P., (1987), Revised Bibliography, "Nirvāṇa", in: Encyclopedia of Religion, Second Edition, Lindsay JoNES, editor in chief, vol. 10: Necromancy-Pindar, Thomson Gale, Macmillan Reference USA.

[31] — . "Nirvānaa", in: Buddhism and Asian History, edited by Joseph Mitsuo Kitagawa and Mark D. Cummings, New York, 1989.

[32] Lacoste, Jean-Yves, editor, Encyclopedia of Christian Theology, vol. 2: G-M, Routledge, Madison Avenue, New York • London, 2005.

[33] MASAO, A., "Dōgen on Buddha-nature," The Eastern Buddhist, IV/1, 1971.

[34] Nellas, Panayotis, Deification in Christ: Orthodox Perspectives on the Nature of the Human Person, Crestwood, NY: SVS Press, 1987.

[35] Parrinder, Geoffrey, Mysticism in the World's Religions, Oneworld Publications, Oxford, 1995.

[36] Rus, Dr. Remus, „Concepţia despre om în marile religii” ("The conception of man in the great religions”), in: Glasul Bisericii, Bucharest: Institutul Biblic şi de Misiune al B.O.R. Publisher, 1978, no. 7-8.

[37] RuSSELL, Norman, The Doctrine of Deification in the Greek Patristic Tradition, Oxford Early Christian Studies, General Editors: Gillian Clark \& Andrew Louth, Oxford University Press Inc., New York, 2004.

[38] SCHWARZ, Hans, "Heaven", in The Cambridge dictionary of Christian Theology, Edited by Ian A. Mcfarland, David A. S. Fergusson, Karen Kilby, Iain R. Torrance, Cambridge University Press, 2011.

[39] —. Eschatology, Wm. B. Eerdmans Publishing Company/Cambridge, UK, 2000.

[40] SIEGMUND, G., Buddhismus und Christentum. Vorbereitung eines Dialogs, 2.Aufl., Steyler Verlag - Sankt Augustin, 1983.

[41] SmarT, Ninian, Concept and Empathy. Essays in the Study of Religion, edited by Donald Wiebe, Library of Philosophy and Religion, General Editor: John Hick, Macmillan Press LTD, 1986.

[42] SoPHrony, (Sakharov), Archimandrite, We Shall See Him as He Is, Trans. Rosemary Edmonds, Tolleshunt Knights: Stavropegic Monastery of St John the Baptist, 1988.

[43] Stăniloae, Dumitru, Teologia Dogmatică Ortodoxă (Orthodox Dogmatic Theology), vol. I, Institutul Biblic şi de Misiune al B.O.R. Publishing House, Bucharest, 1978.

[44] STRENG, Frederick J., Emptiness: A Study in Religious Meaning, New York, 1967.

[45] TsERING, Geshe Tashi, Foundation of Buddhist Thought, vol. I, The Four Noble Truths, Wisdom Publications, Somerville, 2005.

[46] Vallée Poussin, Louis de la, The Way to Nirvāna. Six lectures on ancient Buddhism as a discipline of salvation, Cambridge: at the University Press, 1917.

[47] Walshe, M. O' C., "Buddhism and Christianity: A Positive Approach" (With Some Notes on Judaism), Buddhist Publication Society, Kandy • Sri Lanka, 1986.

[48] WeLbon, Guy R., The Buddhist Nirvāna and Its Western Interpreters, Chicago, 1968.

[49]Zizioulas, J. D., "Human Capacity and Human Incapacity: A Theological Exploration of Personhood," in: Scottish Journal of Theology, (SJTh) 28, Edinburgh, 1975. 